\title{
Carbon storage in the Mediterranean upland shrub communities of Montesinho Natural Park, northeast of Portugal
}

\section{Felícia Fonseca, Tomás de Figueiredo \& M. A. Bompastor Ramos}

\section{Agroforestry Systems}

An International Journal incorporating Agroforestry Forum

ISSN 0167-4366

Agroforest Syst

DOI 10.1007/s10457-012-9509-5

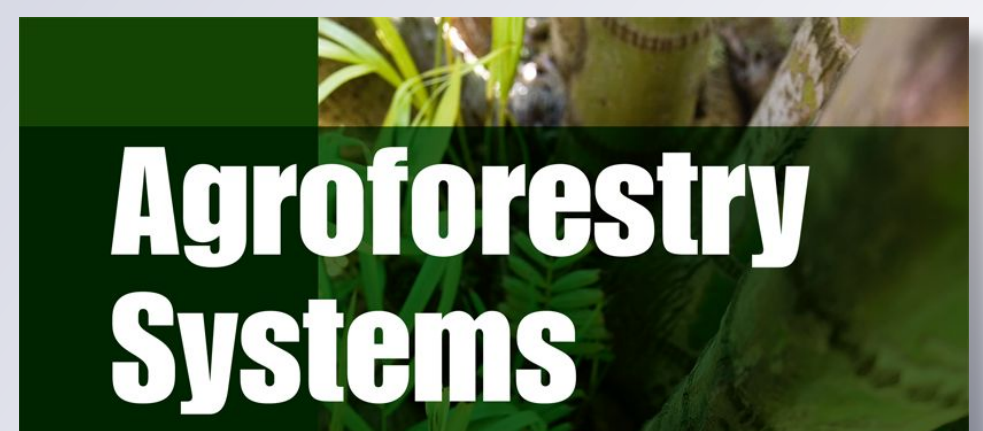

An international journal in cooperation with ICRAF

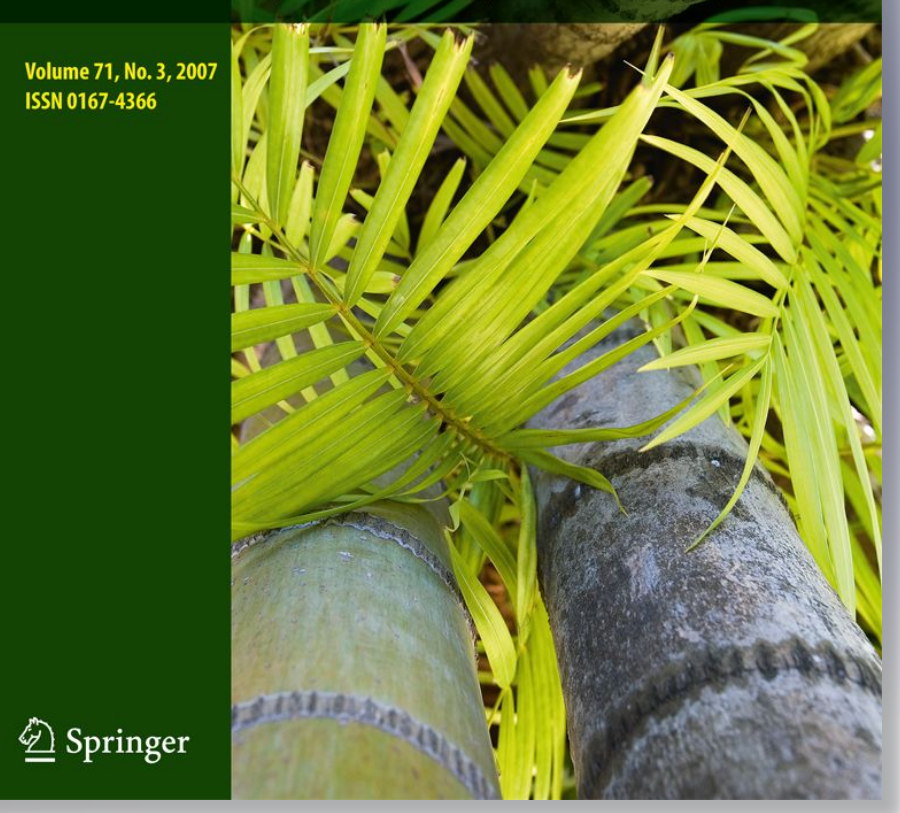

\section{包 Springer}


Your article is protected by copyright and all rights are held exclusively by Springer Science+Business Media B.V.. This e-offprint is for personal use only and shall not be selfarchived in electronic repositories. If you wish to self-archive your work, please use the accepted author's version for posting to your own website or your institution's repository. You may further deposit the accepted author's version on a funder's repository at a funder's request, provided it is not made publicly available until 12 months after publication. 


\title{
Carbon storage in the Mediterranean upland shrub communities of Montesinho Natural Park, northeast of Portugal
}

\author{
Felícia Fonseca • Tomás de Figueiredo • \\ M. A. Bompastor Ramos
}

Received: 12 April 2011/ Accepted: 10 March 2012

(C) Springer Science+Business Media B.V. 2012

\begin{abstract}
Carbon storage is one of the several important functions of shrub communities in terrestrial ecosystems and could represent an effective way to mitigate climate change. Accordingly, biomass carbon (above and belowground), litter carbon, and soil organic carbon (SOC) were studied in three shrub species: Cistus ladanifer (C. ladanifer), Cytisus multiflorus (C. multiflorus), and Erica australis spp. Aragonensis (E. australis)—representing dominant shrub communities found in Montesinho Natural Park (PNM), NE Portugal. The experimental design envisaged testing the effects of species and topography on variables mentioned and procedures carried out included assessments in areas covered by the three communities mentioned, in different topographic conditions (gentle slope, about $5 \%$; moderate, around $15 \%$; steep, around $25 \%$ ), with three replicates. Above and belowground biomass and litter were collected in 1 $\mathrm{m} 2$ plots, where soil samples at depths of 0-5, 5-10, and $10-20 \mathrm{~cm}$ were taken (disturbed for $\mathrm{C}$ mass concentration, undisturbed for bulk density determinations). The aboveground biomass was separated in
\end{abstract}

M. A. Bompastor Ramos is a Master degree student.

F. Fonseca $(\bowtie) \cdot$ T. de Figueiredo .

M. A. Bompastor Ramos

Centro de Investigação de Montanha (CIMO),

Instituto Politécnico de Bragança/ESAB, Apartado 1172,

5301-855 Bragança, Portugal

e-mail: ffonseca@ipb.pt stems, branches, branchlets, leaves, and fruits. Carbon mass concentrations determined in biomass, litter, and soil were converted to $\mathrm{kg} \mathrm{C} \mathrm{m}^{-2}$ ground area. Results showed that: (1) under the conditions studied, over $80 \%$ of carbon is stored in the soil; (2) the contribution of biomass is higher in E. australis, representing about $20 \%$ of carbon storage in the system; (3) for total carbon storage in the whole system, species followed the pattern E. australis $\left(12.8 \mathrm{~kg} \mathrm{C} \mathrm{m}^{-2}\right)>C$. ladanifer $\left(10.5 \mathrm{~kg} \mathrm{C} \mathrm{m}^{-2}\right) \cong$ C. multiflorus $\left(10.5 \mathrm{~kg} \mathrm{C} \mathrm{m}^{-2}\right)$; (4) effects of topographic conditions were not significant in the global $\mathrm{C}$ storage, with 10.6, 11.6, and $11.7 \mathrm{~kg} \mathrm{C} \mathrm{m}^{-2}$ in gentle slope, moderate, and steep, respectively.

Keywords Carbon stocks - Biomass - Litter · Soil organic carbon

\section{Introduction}

During the last century, the $\mathrm{CO}_{2}$ concentration in the atmosphere increased from 280 to $367 \mathrm{ppm}$ (IPCC 2001) and the carbon cycle in terrestrial ecosystems has a recognized key role in regulating actual levels and trends in that concentration (Dixon et al. 1994; Houghton et al. 2000). Besides its scientific interest, the issue is part of international policies that committed countries with actions towards sustainable development (e.g., Kyoto protocol). In this context, reduction of atmospheric $\mathrm{C}$ gases results from both 
emission decrease and increased sequestration in biomass pools (IPCC 2001). As far as control and efficiency in $\mathrm{C}$ sequestration is concerned, agroforestry has a relevant share among those systems based on primary productivity, taken either in the ecological or in the socio-economic sense, and this is one of the significant ecosystem services agroforestry is currently providing (José 2009; Mosquera-Losada et al. 2009).

Agroforestry generally accommodates spatially distributed agricultural and forest activities, managed in an articulated way that may include common or shared practices (Nuberg et al. 2009). In rural areas, land-use and land-ownership patterns are mutually conditioned, generating spatial complexity, further increased by past and actual trends of evolution, quite evident in those affected by negative changes in landuse intensity, in the end leading to agricultural land abandonment (Cerqueira et al. 2010; Nunes 2008). This is especially the case of upland areas, traditionally with agro-silvopastoral production systems, less intensive when compared to those dominant in lowlands. Highlands are actually under pressure in what concerns farm socio-economic and territorial sustainability (Aguiar et al. 2009), and, as set-aside grows, shrub covered areas tend to increase (Kuemmerle et al. 2008). Scrubland spots are, as they have always been, an integral part of land-use systems in mountain areas, and their increased spatial relevance, nowadays coupled with the recognized ecosystems services they provide, presents a multiple-target challenge for traditional agro-ecosystems (Bompastor et al. 2009; IPB/ICN 2006).

Productive functions are assigned to shrub spots, and grazing is often an important one, mainly by sheep flocks in the Portuguese highlands. Fire prevention of planted forest tracts is often performed through prescribed fire to reduce fuel in the neighboring shrubland. As well, reduction of ignitable fuel is also achieved allowing sheep grazing in shrubland, managed by shepherds that sometimes used fire to improved vegetation quality of those extensive grazing areas. Since long, they were biomass pools where litter bed material was collected for manure, a currently declining practice, as well as that of collecting fuel for house heating. Shrubs are currently and traditionally integrated in upland production systems' management, either strictly forest-based, or mixedfarming, or even broader based agro-silvopastoral
(Aguiar et al. 2009; Castro 2010; Figueiredo 2010; Lázaro and Montiel 2010; Montiel and Herrero, 2010). Furthermore, shrub covered areas provide many ecosystems services, that include soil conservation, water quality improvement, biodiversity preservation, and carbon storage, most of them with wide relevance in mountain areas, as these are also the headwaters of main river basins (Bompastor et al. 2009; Figueiredo 2010; IPB/ICN 2006; José 2009). Thus, it is important to stress that, in the interest of society; economic benefits should be provided to landowners or users for land-use and management practices that allow the maintenance of environmental services (FAO 2007).

Carbon storage in above and belowground biomass, in litter, and in mineral soil is one of the several important functions of shrub communities in terrestrial ecosystems, native or productive. These communities accumulate carbon both in biomass and in soil organic matter, except if disturbance occurs. Estimating carbon stocks and their distribution in different compartments of ecological and production systems is essential to understand the amount to which carbon is allocated to labile and stable components (Sierra et al. 2007). This information is also important to evaluate the quantity of carbon that is potentially emitted to the atmosphere when natural or human-induced disturbance occurs in those areas. Actually, the knowledge of shrub communities' effects on carbon stocks is still scarce around the world. However, shrub vegetation may require much closer attention if set-aside (meaning conversion of agricultural land use to native vegetation) is included as a carbon sink under the international policy core acts (Coomes et al. 2002; MacClaran et al. 2008).

According to Rees et al. (2005), there is a scientific obligation to improve the understanding of the processes contributing to carbon storage in terrestrial ecosystems. Soil organic carbon is the most important part of the terrestrial carbon pool and plays a crucial role in the global carbon cycle (Tang et al. 2006; Zhang et al. 2008), containing about twice as much carbon as the atmospheric $\mathrm{CO}_{2}$ reservoir (Percival et al. 2000). It is essential, therefore, to better understand the dynamics of soil carbon (Post and Kwon 2000; Sharma and Rai 2007), and its contribution to carbon storage in systems such as shrub communities.

Shrub communities increased in area in northeast of Portugal over the last years (Aguiar et al. 1992), which is mainly explained by an increase in forest fire 
occurrence and by the increasing abandonment of agricultural land. For this reason shrubs, which account for about one-third of the 75,000 ha of Montesinho Natural Park (PNM), are an important component of land cover and should play a significant role in the carbon balance of this region (Castro et al. 2010; IPB/ICN 2006). The objective of this study was to quantify the biomass, litter, and soil carbon storage for three shrub species (Cistus ladanifer, Cytisus multiflorus, and Erica australis spp. Aragonensis), dominant in the PNM, NE Portugal, which are also common in Mediterranean landscapes, aimed at using this data to evaluate their contribution to regional carbon stocks.

\section{Materials and methods}

Study area

The present study was carried out in PNM, which is a protected area located in the northeast of Portugal from $41^{\circ} 43^{\prime} 47^{\prime \prime}$ to $41^{\circ} 59^{\prime} 24^{\prime \prime} \mathrm{N}$ and $6^{\circ} 30^{\prime} 53^{\prime \prime}$ to $7^{\circ} 12^{\prime} 9^{\prime \prime} \mathrm{W}$, covering around 75,000 ha (Fig. 1). PNM presents a heterogeneous relief, with plateaux cut by deep valleys and some mountains, with slopes varying from flat to very steep. The altitudes range between 438 and 1,486 m asl. A large part of PNM is supra-mediterranean, annual average temperature being of $8-12{ }^{\circ} \mathrm{C}$ and annual average precipitation of 1,000-1,600-mm, concentrated from October to March (IPB/ICN 2006). Schist is the widest represented soil parent material, but basic rocks, ultramafic rocks, granites, and migmatites are lithological groups relatively important in the area.
The spatial distribution of the soil groups shows the strong dominance of Leptosols $(77.1 \%)$ followed by Cambisols (20.1\%), the well developed soils (Luvisols and Alisols) covering $2 \%$ of the territory (Agroconsultores and Coba 1991; Figueiredo 1990). The native vegetation is Quercus pyrenaica but its dramatic reduction in recent centuries led to the degradation of soils that are now basically covered by shrub species (Aguiar et al. 1992). Currently the shrub communities are considered stable components of the landscape (Figueiredo 1990).

Sampling design and technique, sample treatment

Data were obtained in June 2007, the time of year that, for most species, corresponds to maximum production of biomass, either aboveground (Arevalo et al. 2009; Lufafa et al. 2008) or belowground (Curt et al. 2001). The shrub covered area surveyed is in the NE part of $\mathrm{PNM}$, at $900 \mathrm{~m}$ elevation, where the main shrub communities can be found in a short distance range. Three sites, located on schist derived Umbric Leptosols, were selected for sampling, each covered by one of the three dominant shrub communities (Cistus ladanifer, Cytisus multiflorus, and Erica australis spp. aragonensis), and with variable slope gradient according to topographical position (gentle on crest, about $5 \%$; moderate on shoulder, around $15 \%$; steep on mid-slope, around $25 \%$ ). In each site, nine plots of $1 \times 1 \mathrm{~m}$ were established along the hill-slope (three replicates per slope gradient), so as to include shrub plants between 60 and $80 \mathrm{~cm}$ height. The choice of such a range in plant height followed local observation which allowed considering a reference plant size for comparing the different shrub communities studied.
Fig. 1 Location of the study area in Montesinho Natural Park (PNM), NE Portugal (shrub cover represented by colored areas). (Color figure online)

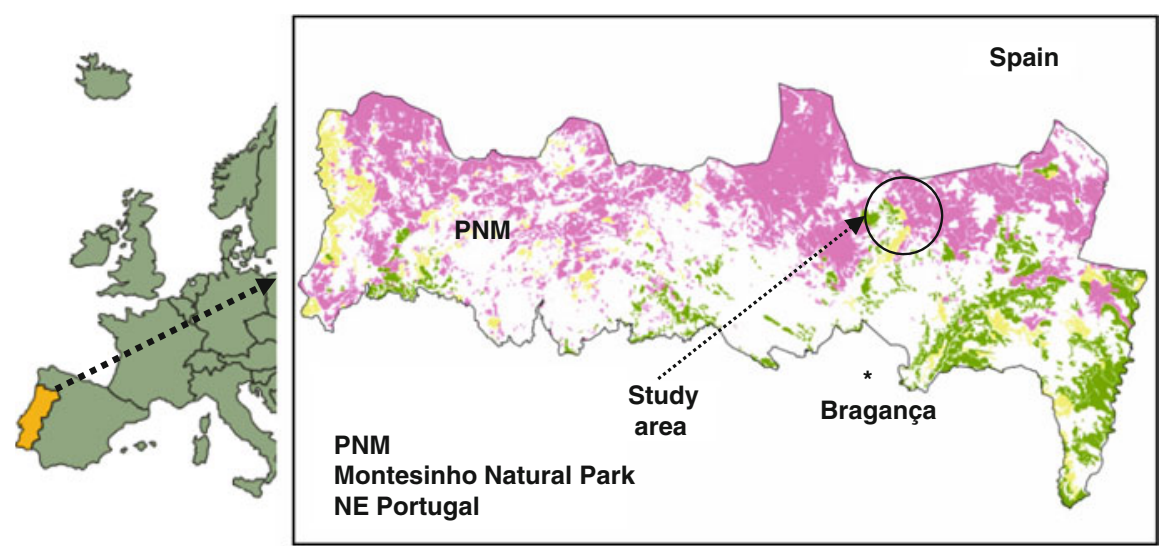


Besides, it should be noted that the mentioned plant height accommodated requirements concerning vegetation size imposed by erosion experiments carried out in these areas with a portable rainfall simulator (Bompastor et al. 2009).

In each plot, total height and crown cover of shrubs were measured. Then shrubs were clipped and roots were excavated to evaluate biomass in the above and belowground components, respectively. Aboveground biomass was separated in fruits, leaves, branchlets, branches, and stems. Samples of fruits were collected from $C$. ladanifer $(n=9)$ and C. multiflorus $(n=5)$ and leaves only in $C$. ladanifer $(n=9)$, because, unlike the remaining plant components, these were not present in all plots $(n=27)$. Other components (branchlets, branches, stems, and roots) were collected from all plots ( $n=9$ each component and species). The excavation depth for sampling the belowground biomass varied with rooting species patterns. Because the soils are very shallow and stony (Umbric Leptosols of schist), the root systems were concentrated in the base of the shrubs, reaching relatively low depths rarely exceeding $50 \mathrm{~cm}$. To collect the roots it was often necessary to move large quantities of stones to reach the end of some roots. The $C$. multiflorus and C. ladanifer species reached higher depths around $55 \mathrm{~cm}$, while the E. australis species did not exceed $40 \mathrm{~cm}$ in depth. Total root biomass was determined without separation by diameter classes. Silva et al. (2003) refer in similar soils (Lithossols of schist) located in the Central East Region of Portugal (Serra da Malcata) the maximum rooting deep of 35 and $60 \mathrm{~cm}$ for species Erica australis and Cytisus multiflorus, respectively. Root:shoot ratio was computed, for each plot, with the amount of $\mathrm{C}$ in below ground biomass and that of total above ground biomass.

The litter was defined as organic material deposited over mineral soil and entirely collected, after measuring thickness in five points randomly selected over plot ground. Biomass and litter samples were dried at $65{ }^{\circ} \mathrm{C}$ for $72 \mathrm{~h}$ to determine dry mass. Total soil organic $\mathrm{C}$ down to $20 \mathrm{~cm}$ depth in the plots was calculated from $\mathrm{C}$ concentrations in soil cores collected in the $0-5,5-10$, and 10-20 cm soil layers and from soil bulk density at the same depths. Because the soils are very shallow and stony, soil sampling was only possible in these depths. Bulk density was determined in undisturbed samples, weighting ovendried soil (at $105{ }^{\circ} \mathrm{C}$ ), collected in $100 \mathrm{~cm}^{3}$ cylinders.
Samples for soil $\mathrm{C}$ were air dried and sieved to determine the coarse fraction $(>2-\mathrm{mm})$.

All samples of biomass components, litter, and mineral soil were analyzed for total $\mathrm{C}$ by dry combustion (ISO 1994). Soil samples were tested with an acid-drop but no carbonates were detected, thus the total soil $\mathrm{C}$ was assumed to be comparable to soil organic C. Biomass and litter mass values were converted to carbon (expressed in $\mathrm{kg} \mathrm{C} \mathrm{m}^{-2}$, given the size of the area sampled) multiplying these values by the $\mathrm{C}$ concentration in dry matter. Soil organic carbon $\left(C_{\mathrm{SOC}}, \mathrm{kg} \mathrm{C} \mathrm{m}^{-2}\right)$ was calculated multiplying $\mathrm{C}$ concentration $\left(C_{\mathrm{c}}, \mathrm{g} \mathrm{kg}^{-1}\right)$ by bulk density $\left(\mathrm{BD}, \mathrm{g} \mathrm{cm}^{-3}\right)$ and thickness $(z, \mathrm{~cm})$ of the mineral soil layer with a correction for coarse elements content $\left(\mathrm{CE}, \mathrm{v} \mathrm{v}^{-1}\right)$ using the following equation (Percival et al. 2000; Tate et al. 1997):

$$
\mathrm{C}_{\mathrm{SOC}}=\mathrm{zC}(\mathrm{BD}-2.65 \mathrm{CE} / 100)
$$

The total carbon storage (TC) per unit area $\left(\mathrm{kg} \mathrm{C} \mathrm{m}^{-2}\right.$ ) was estimated by summing the mean amount of carbon in different pools:

$\mathrm{TC}=\mathrm{C}_{\mathrm{AB}}+\mathrm{C}_{\mathrm{L}}+\mathrm{C}_{\mathrm{SOC}}$

where $C_{\mathrm{AB}}$ is carbon content in above and belowground biomass, $C_{\mathrm{L}}$ is carbon content in litter, and $C_{\text {SOC }}$ is carbon content in soil.

\section{Statistical analysis}

Two-way ANOVA tested the effects of Species and Topography (with 2 degrees of freedom assigned to each one of these factors and 4 to their interaction) on each variable assessed, except in the case explained below. Following ANOVA, Turkey tests allowed statistical comparison of variable means at $P<0.05$ level for the significant experimental design factors and interactions (Steel and Torrie 1980).

In what concerns carbon in plant biomass, differences were hypothesized between plant components in their $\mathrm{C}$ concentration and $\mathrm{C}$ contents. In these cases, the two-way ANOVA comprised the effects of species and components, and their interaction (the latter with 4 degrees of freedom), as there is no sound experimental basis to state topography as a factor conditioning $\mathrm{C}$ concentration and $\mathrm{C}$ contents in plant biomass.

Correlation and linear regression, simple and multiple, were also part in the statistical analysis of data. Analyses were performed using 11.5 version of the SPSS software. 


\section{Results}

$\mathrm{C}$ in above and belowground biomass

\section{C concentration}

Carbon concentration in biomass was significantly affected by the factors under test, namely plant species and components, and their interaction (Fig. 2). Average values range from $55.3 \%$ in C. ladanifer to $56.3 \%$ in E. australis, a $1 \%$ difference that is statistically significant. Differences higher than these occurred between average $\mathrm{C}$ concentrations in the biomass components. Lowest $\mathrm{C}$ concentration was found in roots $(53.6 \%)$ and highest in stems $(57.0 \%)$. Branchlets and branches, with a similar mean (56.1 $\%$ ), are the only components, which values do not show statistically significant differences. This general pattern was actually followed by $C$. multiflorus but, for $C$. ladanifer and E. australis, differences between components were all statistically significant. The low data scatter, as indicated by a global CV as low as $3 \%$ about a general average of $55.8 \% \mathrm{C}$ concentration in biomass, may explain the results of statistical tests. In spite of these, data highlight the narrow range of $\mathrm{C}$ concentration found in biomass in these ecosystems, as $80 \%$ of data fall within a range of $3.5 \% \mathrm{C}$, and $90 \%$ of data fall within a range of $4.9 \% \mathrm{C}$. This data consistency may seemingly be assigned to species and component specificity.

\section{C storage}

For C. multiflorus and E. australis approximately $75 \%$ of the aboveground $\mathrm{C}$ was stored in stems and branchlets together, this latter component representing the largest fraction (41 and $46 \%$ for C. multiflorus and E. australis, respectively). For both components, the E. australis $\mathrm{C}$ storage was significantly higher when compared to the other species. In C. ladanifer, stems account for $41 \%$ of all $\mathrm{C}$ accumulated in the aboveground biomass, the leaves $30 \%$, and, unlike other species, branchlets represent less than $6 \%$ (Fig. 3). Total biomass $\mathrm{C}$ storage varied significantly with respect to shrub species and non-significantly with slope (Fig. 4). The amounts of belowground $\mathrm{C}$ ranged between 0.17 ( $C$. multiflorus) and $2.36 \mathrm{~kg} \mathrm{C} \mathrm{m}^{-2}$ (E. australis) and of aboveground ranged between 0.46 and $0.80 \mathrm{~kg} \mathrm{C} \mathrm{m}^{-2}$ for the same species. E. australis had the largest global biomass $\mathrm{C}$ stock (above and belowground), significantly different from the other two species (Table 1). For this species, the belowground fraction is $1.71 \mathrm{~kg} \mathrm{C} \mathrm{m}^{-2}$, meaning $71 \%$ of total biomass $\mathrm{C}$ stock, whereas other species have much lower proportions. On the contrary, a relatively smaller $\mathrm{C}$ amount $\left(0.69 \mathrm{~kg} \mathrm{C} \mathrm{m}^{-2}\right)$ is found in E. australis aboveground fractions, when compared to the other species (Table 1; Fig. 4).

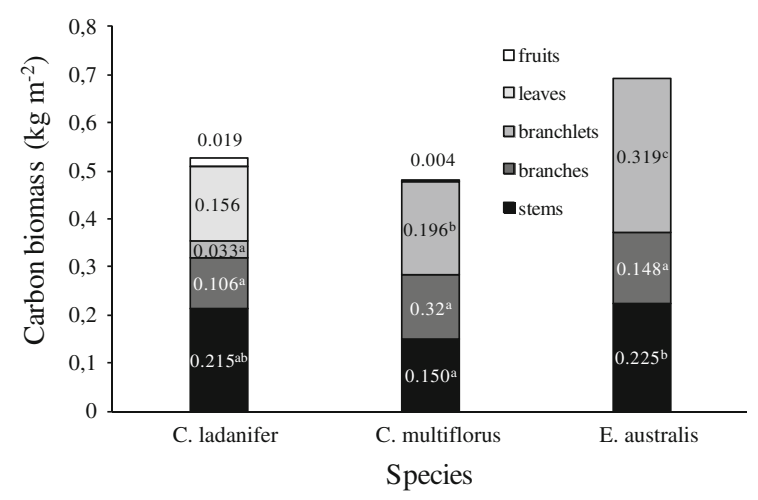

Fig. 3 Carbon in aboveground biomass components $\left(\mathrm{kg} \mathrm{C} \mathrm{m}^{-2}\right)$ : means for each species. Average values of each biomass component with the same letter are not significantly different $(P>0.05)$
Fig. 2 Carbon concentration in biomass $(\%)$ : mean \pm standard deviation for plant species (a) and components (b). For each one of these variables, averages followed by the same letter are not significantly different $(P>0.05)$
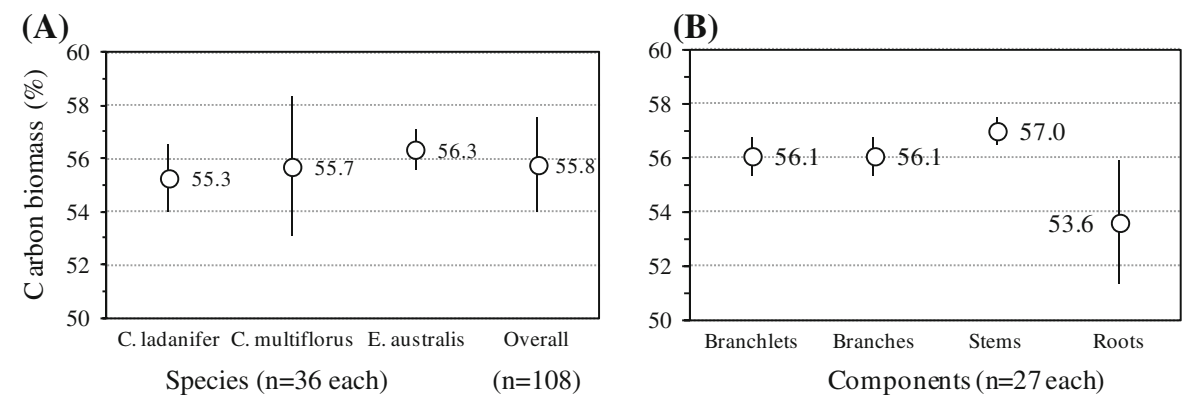
Fig. 4 Carbon in above (AGC) and belowground (BGC) biomass $\left(\mathrm{kg} \mathrm{C} \mathrm{m}^{-2}\right)$ in relation to species (a) and slope (b). Numbers above bars indicate total $\mathrm{C}$ in biomass; numbers inside bars indicate percentage $\mathrm{C}$ in belowground biomass. For species or slope, averages with the same letter are not significantly different $(P>0.05)$

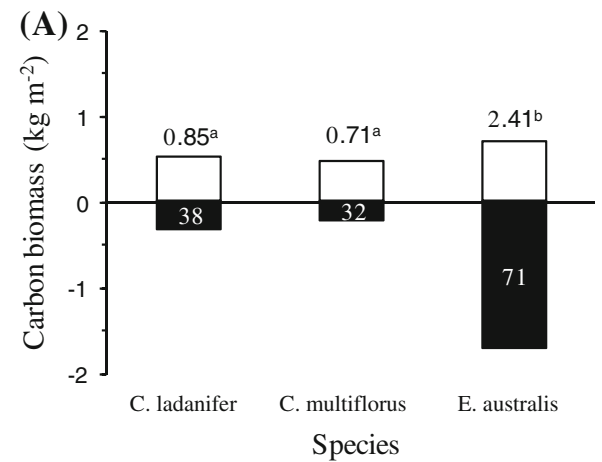

The root:shoot ratio mean values were significantly affected by both shrub species and slope, the highest value being calculated for $C$. multiflorus (2.09) and the lowest for E. australis (0.40) (Table 1).

Aboveground biomass (AGB) shows a significant correlation with crown cover (CC) and total height $(\mathrm{TH})$ of shrubs, considered together in multiple regression analysis:

$$
\begin{aligned}
\mathrm{AGB}= & -411.343+6.904 \mathrm{TH} \\
& +15.181 \mathrm{CC}\left(\mathrm{r}^{2}=0.382, P<0.003\right)
\end{aligned}
$$

Table 1 Average above and belowground carbon storage $\left(\mathrm{kg} \mathrm{C} \mathrm{m}^{-2}\right)$ and root:shoot ratio in relation to slope and species. For species or slope, overall means of each variable with

\begin{tabular}{|c|c|c|c|c|}
\hline \multirow[t]{2}{*}{ Slope } & \multicolumn{3}{|l|}{ Species } & \multirow[t]{2}{*}{ Overall } \\
\hline & $\begin{array}{l}C . \\
\text { ladanifer }\end{array}$ & $\begin{array}{l}\text { C. } \\
\text { multiflorus }\end{array}$ & $\begin{array}{l}\text { E. } \\
\text { australis }\end{array}$ & \\
\hline \multicolumn{5}{|c|}{ Aboveground $\mathrm{C}$ storage $\left(\mathrm{kg} \mathrm{m}^{-2}\right)$} \\
\hline Gentle & 0.57 & 0.51 & 0.80 & 0.63 \\
\hline Moderate & 0.52 & 0.48 & 0.67 & 0.56 \\
\hline Steep & 0.50 & 0.46 & 0.60 & 0.52 \\
\hline Overall & $0.53^{\mathrm{a}}$ & $0.48^{\mathrm{a}}$ & $0.69^{\mathrm{b}}$ & \\
\hline \multicolumn{5}{|c|}{ Belowground $\mathrm{C}$ storage $\left(\mathrm{kg} \mathrm{m}^{-2}\right)$} \\
\hline Gentle & 0.42 & 0.29 & 1.08 & 0.60 \\
\hline Moderate & 0.21 & 0.23 & 1.69 & 0.71 \\
\hline Steep & 0.32 & 0.17 & 2.36 & 0.95 \\
\hline Overall & $0.32^{\mathrm{a}}$ & $0.23^{\mathrm{a}}$ & $1.71^{\mathrm{b}}$ & \\
\hline \multicolumn{5}{|c|}{ Root:shoot ratio } \\
\hline Gentle & 0.74 & 0.57 & 1.35 & 0.95 \\
\hline Moderate & 0.40 & 0.48 & 2.52 & 1.70 \\
\hline Steep & 0.64 & 0.37 & 3.93 & 1.37 \\
\hline Overall & $0.60^{\mathrm{a}}$ & $0.48^{\mathrm{a}}$ & $2.48^{\mathrm{b}}$ & \\
\hline
\end{tabular}
the same letter are not significantly different $(P>0.05)$

\section{Litter C storage}

C. ladanifer shows the highest $\mathrm{C}$ concentration in litter (50\%), followed by C. multiflorus (47\%), and by E. australis $(38 \%)$.

Litter carbon storage and litter layer thickness in the C. ladanifer were significantly higher than those of other shrub species. Carbon accumulation in the litter was similar in all slopes, but the thickness was significantly lower in gentle and steep slope gradients (Table 2). The litter layer was very thin $(0.12-2.50 \mathrm{~cm})$, with the lowest values in E. australis and in steep slope.

A strong positive correlation was observed between litter C storage (LCS) and litter layer thickness (LT), and this may be helpful for litter $\mathrm{C}$ storage estimates, based on a much simpler to assess parameter as litter thickness. The regression equation is:

$$
\begin{aligned}
& \begin{array}{l}
\text { LCS }=0.1229 \mathrm{LT} \\
+0.0437 \quad\left(\mathrm{r}^{2}=0.81, P<0.000\right)
\end{array} \\
& \text { Soil C storage }
\end{aligned}
$$

\section{Soil C storage}

Organic C concentrations in soils decreased with increasing depth in all shrub species and slopes, showing values generally over $50 \mathrm{~g} \mathrm{C} \mathrm{kg}^{-1}$ of soil (Table 3). The concentration of soil organic carbon (SOC) in the first $5 \mathrm{~cm}$ ranged from $68.6 \mathrm{~g} \mathrm{~kg}^{-1}$ (C. ladanifer) to $81.0 \mathrm{~g} \mathrm{~kg}^{-1}$ (E. australis) and reveals significant differences between them.

The $0-20 \mathrm{~cm}$ soil profile contained an average of $9.5,9.6$, and $10.3 \mathrm{~kg} \mathrm{C} \mathrm{m}^{-2}$ in the C. ladanifer, C. multiflorus, and E. australis, respectively (Fig. 5). In this study, bulk density differed significantly 
Table 2 Litter carbon storage $\left(\mathrm{kg} \mathrm{C} \mathrm{m}^{-2}\right)$ and litter layer thickness $(\mathrm{cm})$ in relation to slope ( $n=9$ each slope) and species ( $n=9$ each specie), expressed as mean and standard deviation. For species or slope overall means with the same letter across columns and rows are not significantly different $(P<0.05)$

\begin{tabular}{|c|c|c|c|c|}
\hline \multirow[t]{2}{*}{ Slope } & \multicolumn{3}{|l|}{ Species } & \multirow[t]{2}{*}{ Overall } \\
\hline & C. ladanifer & C. multiflorus & E. australis & \\
\hline \multicolumn{5}{|c|}{ Litter $\mathrm{C}$ storage $\left(\mathrm{kg} \mathrm{m}^{-2}\right)$} \\
\hline Gentle & $0.28 \pm 0.08$ & $0.13 \pm 0.03$ & $0.10 \pm 0.09$ & $0.17 \pm 0.10$ \\
\hline Moderate & $0.34 \pm 0.07$ & $0.10 \pm 0.11$ & $0.07 \pm 0.01$ & $0.17 \pm 0.14$ \\
\hline Steep & $0.22 \pm 0.06$ & $0.11 \pm 0.07$ & $0.02 \pm 0.01$ & $0.12 \pm 0.9$ \\
\hline Overall & $0.28 \pm 0.08^{\mathrm{b}}$ & $0.12 \pm 0.07^{\mathrm{a}}$ & $0.06 \pm 0.05^{\mathrm{a}}$ & \\
\hline \multicolumn{5}{|c|}{ Thickness of litter layer $(\mathrm{cm})$} \\
\hline Gentle & $1.67 \pm 0.76$ & $0.67 \pm 0.29$ & $0.38 \pm 0.33$ & $0.91 \pm 0.69^{\mathrm{ab}}$ \\
\hline Moderate & $2.50 \pm 0.50$ & $0.75 \pm 0.25$ & $0.23 \pm 0.06$ & $1.16 \pm 1.01^{\mathrm{b}}$ \\
\hline Steep & $1.50 \pm 0.50$ & $0.28 \pm 0.19$ & $0.12 \pm 0.03$ & $0.63 \pm 0.67^{\mathrm{a}}$ \\
\hline Overall & $1.89 \pm 0.66^{\mathrm{b}}$ & $0.57 \pm 0.29^{\mathrm{a}}$ & $0.24 \pm 0.19^{\mathrm{a}}$ & \\
\hline
\end{tabular}

Table 3 Carbon concentrations $\left(\mathrm{g} \mathrm{C} \mathrm{kg}^{-1}\right)$, mineral soil bulk density $\left(\mathrm{g} \mathrm{cm}^{-3}\right)$ and coarse elements percentage in the three layers of mineral soil according to slope $(n=9$ each slope and layer) and species ( $n=9$ each specie and layer), expressed as mean and standard deviation. For species or slope, averages with the same letter among rows are not significantly different $(P<0.05)$

\begin{tabular}{|c|c|c|c|c|c|c|}
\hline \multirow[t]{2}{*}{ Depth $(\mathrm{cm})$} & \multicolumn{3}{|l|}{ Species } & \multicolumn{3}{|l|}{ Slope } \\
\hline & C. ladanifer & C. multiflorus & E. australis & Gentle & Moderate & Steep \\
\hline \multicolumn{7}{|c|}{ SOC concentrations $\left(\mathrm{g} \mathrm{kg}^{-1}\right)$} \\
\hline $0-5$ & $68.6 \pm 11.8^{\mathrm{a}}$ & $69.5 \pm 17.6^{\mathrm{a}}$ & $81.0 \pm 7.3^{\mathrm{b}}$ & $66.3 \pm 11.4$ & $70.8 \pm 15.2$ & $76.2 \pm 22.6$ \\
\hline $5-10$ & $59.2 \pm 8.5$ & $61.1 \pm 10.6$ & $69.6 \pm 4.8$ & $56.3 \pm 9.6$ & $67.2 \pm 7.8$ & $66.4 \pm 6.2$ \\
\hline $10-20$ & $45.9 \pm 6.5$ & $50.6 \pm 8.4$ & $56.8 \pm 7.0$ & $45.6 \pm 4.6$ & $56.0 \pm 7.0$ & $51.7 \pm 9.9$ \\
\hline \multicolumn{7}{|c|}{ Bulk density $\left(\mathrm{g} \mathrm{cm}^{-3}\right)$} \\
\hline $0-5$ & $1.18 \pm 0.10^{\mathrm{a}}$ & $1.15 \pm 0.15^{\mathrm{ab}}$ & $1.09 \pm 0.14^{\mathrm{b}}$ & $1.24 \pm 0.13^{\mathrm{a}}$ & $1.08 \pm 0.12)^{\mathrm{b}}$ & $1.10 \pm 0.09^{\mathrm{b}}$ \\
\hline $5-10$ & $1.25 \pm 0.09$ & $1.24 \pm 0.10$ & $1.20 \pm 0.13$ & $1.24 \pm 0.09$ & $1.26 \pm 0.09)$ & $1.19 \pm 0.14$ \\
\hline $10-20$ & $1.37 \pm 0.11^{\mathrm{a}}$ & $1.32 \pm 0.10^{\mathrm{a}}$ & $1.21 \pm 0.13^{\mathrm{b}}$ & $1.35 \pm 0.15^{\mathrm{a}}$ & $1.24 \pm 0.09)^{\mathrm{b}}$ & $1.30 \pm 0.11^{\mathrm{ab}}$ \\
\hline \multicolumn{7}{|c|}{ Coarse elements content $(\%)$} \\
\hline $0-5$ & $42.8 \pm 7.1$ & $47.4 \pm 5.4$ & $49.0 \pm 6.3$ & $45.5 \pm 7.0$ & $48.5 \pm 6.5$ & $45.2 \pm 6.5$ \\
\hline $5-10$ & $49.0 \pm 6.7$ & $54.1 \pm 6.8$ & $53.2 \pm 6.1$ & $49.4 \pm 5.9$ & $53.4 \pm 6.4$ & $53.4 \pm 7.6$ \\
\hline $10-20$ & $52.3 \pm 5.0$ & $50.7 \pm 6.5$ & $54.1 \pm 5.5$ & $51.6 \pm 7.6$ & $50.9 \pm 3.3$ & $54.6 \pm 5.2$ \\
\hline
\end{tabular}

between shrub species and slopes at the top layer $(0-5 \mathrm{~cm})$ and the $10-20 \mathrm{~cm}$ layer (Table 3). Bulk density (BD) shows a strong correlation with soil $\mathrm{C}$ concentration $(\mathrm{Cc})$ and can be estimated by the equation:

$$
\begin{aligned}
\mathrm{BD}= & 0.0744 \mathrm{Cc} \\
& +1.6867\left(\mathrm{r}^{2}=0.924, P<0.000\right)
\end{aligned}
$$

For all shrub species the SOC in $0-5 \mathrm{~cm}$ depth was lower in gentle slopes. There was more data scatter in $0-5 \mathrm{~cm}$ (CV of $20.5 \%)$ than that of other soil layers (CV of 16.2 and $14.0 \%$ at the 5-10 and $10-20 \mathrm{~cm}$ depth, respectively). SOC down to $10 \mathrm{~cm}$ depth represented $54.8 \%$ (C. multiflorus), $57.0 \%$ (E. australis), and $58.2 \%$ (C. ladanifer) of the SOC stock for the whole 0-20 $\mathrm{cm}$ soil depth sampled (Fig. 5).

\section{Total C storage}

Total carbon storage in E. australis was $12.8 \mathrm{~kg} \mathrm{C} \mathrm{m}^{-2}$ which was significantly higher than the storage in $C$. ladanifer $\left(10.7 \mathrm{~kg} \mathrm{C} \mathrm{m}^{-2}\right)$ and C. multiflorus (10.5 $\mathrm{kg} \mathrm{C} \mathrm{m}^{-2}$ ) (Fig. 6). The topographical position (slope) had no significant effect on the global carbon storage. The majority of the carbon was located in the soil (E. australis, $80.7 \%$; 
Fig. 5 Total soil organic carbon storage (numbers below bars in $\mathrm{kg} \mathrm{C} \mathrm{m}^{-2}$ ) according to species (a) and slope (b). Numbers inside bars indicate percentage $\mathrm{C}$ in each soil layer

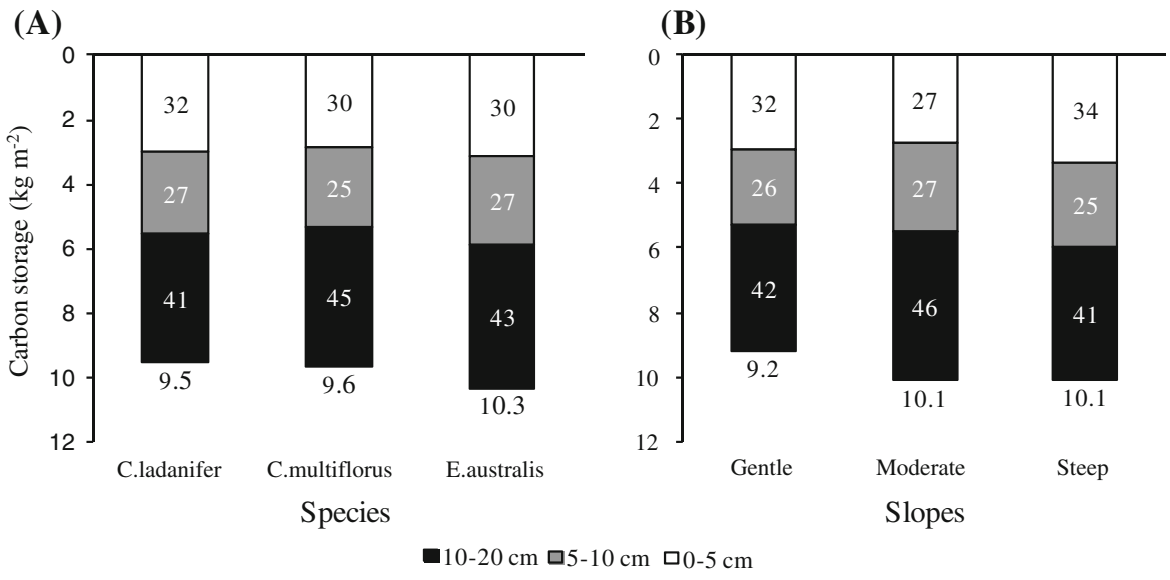

Fig. 6 Total carbon storage in the whole system (numbers above bars in $\mathrm{kg} \mathrm{C} \mathrm{m}{ }^{-2}$ ) according to species (a) and slopes (b) (numbers inside bars indicate percentage $\mathrm{C}$ in each compartment). For species or slope, averages with the same letter are not significantly different $(P>0.05)$

(A)

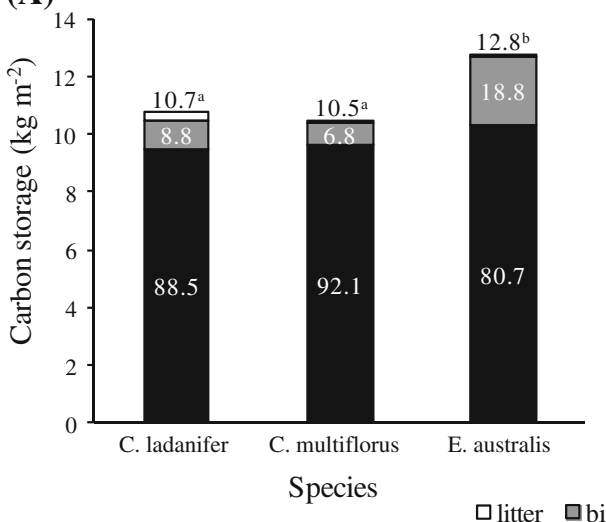

(B)

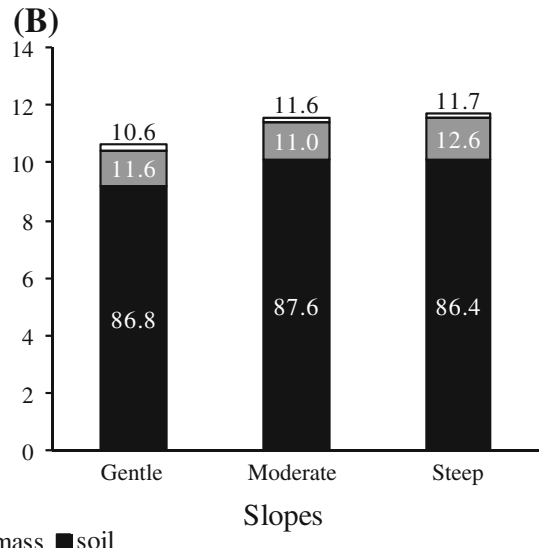

C. ladanifer, $88.5 \%$; and C. multiflorus, $92.1 \%$ ), and for the living biomass (above and belowground) the species ranked inversely, with values of 18.8 ( $E$. australis), 8.8, and $6.8 \%$ (C. multiflorus). The litter accounted for only $0.5,1.1$, and $2.6 \%$ for E. australis, C. multiflorus, and C. ladanifer, respectively.

\section{Discussion}

This study quantified the $\mathrm{C}$ pools of above and belowground biomass, litter and soil in a Mediterranean shrubland in NE Portugal. The knowledge about $\mathrm{C}$ storage in different components of shrub communities could give indication the potential for $\mathrm{CO}_{2}$ release to atmosphere in case these systems suffer human disturbances or fire occurs (Bing et al. 2006; Perez-Quezada et al. 2011; Yimer et al. 2006; Zheng et al. 2008). Average values of $C$ concentration in aboveground biomass components and roots range from $57.0 \%$ in stems to $53.6 \%$ in roots. These values are clearly higher than the $50 \% \mathrm{C}$ concentration in biomass normally assumed in $\mathrm{C}$ estimates (Arevalo et al. 2009; Cerrilo and Oyonarte 2006; Goetz and Prince 1998; Gower et al. 1997; Madeira et al. 2002; Nair 2011; Ordóñez et al. 2008; Pinno and Bélanger 2008). Results obtained rise awareness to the relevant errors that may occur in estimates of $\mathrm{C}$ biomass contents, or $\mathrm{C}$ balances, when applying that $50 \%$ average. Based on data obtained in this study it is proposed, for these species, average values of $56 \% \mathrm{C}$ in aboveground biomass and $54 \%$ in belowground biomass. Accordingly, when determining the amount of $\mathrm{C}$ stored in aboveground biomass based on $\mathrm{C}$ concentration measured in samples of biomass and the proposals in this paper (56 and $54 \%$ is above belowground and biomass, respectively) the differences do not exceed $2 \%$ for all components. However, when it admits a $\mathrm{C}$ concentration $50 \%$ in the biomass, $\mathrm{C}$ storage values decrease about $12 \%$ in aboveground 
biomass and from 3 (C. multiflorus) to $10 \%$ (E. australis) in belowground biomass. Hence, results advise the use of more specific values according to ecosystem and plant component.

While statistical analysis did not outcome significant differences in $\mathrm{C}$ stored between different topographical position (slope), differences were significant between species in what concerns $\mathrm{C}$ stored in either biomass, litter, or soil. Above and belowground biomass $\mathrm{C}$ stock and mineral soil until $5 \mathrm{~cm}$ of depth were significantly higher for E. australis. It seems that the quantity and quality of biomass produced by the different species are the main cause of the differences found among the shrub communities.

Shrub species have various adaptive mechanisms to survive in Mediterranean climate (Keeley 1998; Mooney and Dunn 1970). One of these mechanisms involves a larger allocation of plant resources to root than to shoot fraction (Guilherme et al. 1998; Jurado and Westoby 1992; Lloret et al. 1999), which is possibly an adaptation to the summer water deficit (Hilbert and Canadell 1995). In this study, E. australis species follows this trend with root:shoot ratio that ranged between 1.35 and 3.93 , but the other species (C. ladanifer and C. multiflorus) show values lower than 1. It is common to find root:shoot ratios higher than 1 in arid and semi-arid regions (e.g., Fan et al. 2008; Noy-Meir 1973;). The low root:shoot ratio values observed in C. ladanifer and C. multiflorus species suggest that the relative production of roots and shoots is controlled by species-specific development patterns (Gedroc et al. 1996). The present study helps supporting such statement, as all sampling areas were selected within a range of less than $1 \mathrm{~km}$, under similar soil and climate conditions. Ratios lower than 1 are also reported for semiarid regions of Australia (Fan et al. 2008), Mediterranean arid shrubland in Chile (Perez-Quezada et al. 2011), and California chaparral (Kummerow et al. 1977). The knowledge of root:shoot ratio may be important to estimate the carbon stocks in above and belowground biomass (Ordóñez et al. 2008), particularly in the case of shrub communities, because of data scarcity concerning this type of vegetation cover. It is clear from results obtained that estimates should be species oriented and not rely in general averages.

The $\mathrm{C}$ storage capacity of aboveground biomass ranged from $4.6 \mathrm{Mg} \mathrm{C} \mathrm{ha}^{-1}$ (C. multiflorus) to 5.0 $\mathrm{Mg} \mathrm{C} \mathrm{ha}^{-1}$ (C. ladanifer) and to $8.0 \mathrm{Mg} \mathrm{C} \mathrm{ha}^{-1}$
(E. australis), whereas of belowground biomass ranged between 1.7, 2.1 and 23.6 $\mathrm{Mg} \mathrm{C} \mathrm{ha}^{-1}$ for the same species, respectively. Cerrilo and Oyonarte (2006) reported similar values of aboveground biomass for C. ladanifer (4.9 $\mathrm{Mg} \mathrm{C} \mathrm{ha}^{-1}$ ) and slightly lower for Erica sp. $\left(5.7 \mathrm{Mg} \mathrm{C} \mathrm{ha}^{-1}\right)$ in shrubland ecosystems of southern Spain. As expected these values are high compared to the values obtained by Perez-Quezada et al. (2011) in a Mediterranean arid shrubland in Chile $\left(0.06-3.35 \mathrm{Mg} \mathrm{ha}^{-1}\right.$ of aboveground and $0.02-0.55 \mathrm{Mg} \mathrm{ha}^{-1}$ of belowground biomass for $F$. thurifera and A. saligna species, respectively). Among the different components of aboveground biomass, the largest contribution came from branchlets and stems in C. multiflorus and E. australis. In C. ladanifer, stems and leaves were the most important components for aboveground $\mathrm{C}$ storage. However, stems and branches together represent $54-61 \%$ of $\mathrm{C}$ in aboveground biomass in the three species, providing a relevant $\mathrm{C}$ stock in vegetation, stable either under regular or accidental conditions, as those of fire occurrence, when the less lignified components are selectively burned. Aboveground biomass showed a significant correlation with crown cover and total height of shrubs $\left(r^{2}=0.38\right)$. Despite the low value of $r^{2}$, this information is still relevant to the region because this is the first tool available to estimate shrub aboveground biomass in PNM area.

Litter C storage varied from 0.6 (E. australis) to $2.8 \mathrm{Mg} \mathrm{ha}^{-1}$ (C. ladanifer), and increased with litter $\mathrm{C}$ concentration and thickness. A strong positive correlation was found between litter $\mathrm{C}$ storage and litter thickness $\left(r^{2}=0.81\right)$. The smallest litter accumulation under E. australis can be associated with higher biological degradation rates, confirmed by the lower $\mathrm{C}$ concentration, 38 versus 47 (C. multiflorus) and $50 \%$ (C. ladanifer) (Bing et al. 2006; Klein et al. 2008) and can explain the higher SOC under this species. This is in accordance with the work developed by Vargas et al. (2006) who reported for a microcosm decomposition experiment, using two evergreen shrubs (Atriplex lampa and Junellia seriphioides), the decrease in litter C associated with a significant increase in SOC. Similar concentrations of carbon in litter were reported by Alegre et al. (2004) for Colutea arborescens $(44 \%)$ and Medicago Strasseri (41\%) in cold semiarid Mediterranean conditions (Madrid, Spain). Thus, in permanently vegetated soils, the effects of plant species on ecosystem are related to the quantity 
and quality of litter deposited on soil surface (Alegre et al. 2004; Chojnacky and Milton, 2008; Nicolini and Topp 2005). Despite its minor contribution to total carbon, litter is an important component of the carbon biogeochemical cycle (Ordóñez et al. 2008; Zhang et al. 2007), as it is the interface between vegetation and soil. Such specific location makes it a buffer zone, developed as the balance between time-lagged fluxes, namely incoming $\mathrm{C}$ materials from above ground vegetation layers and out coming $\mathrm{C}$ in organic structures at several stages of decomposition that, in turn, are a relevant input to the soil organic $\mathrm{C}$ pool.

The soil was the largest $\mathrm{C}$ pool representing until $20 \mathrm{~cm}$ of depth 95, 96, and $103 \mathrm{Mg} \mathrm{ha}^{-1}$ for C. ladanifer, C. multiflorus, and E. australis, respectively. These amounts of $\mathrm{C}$ stored in soil reflect the contribution of several influences, primarily identified with differences in biomass production by cover vegetation, for which species ranked as in soil, meaning C. ladanifer and C. multiflorus $<E$. austral$i s$. On the other hand, for organic residues accumulation on ground surface, species ranked as $C$. ladanifer and $C$. multiflorus $>$ E. australis, seemingly meaning more efficient transfer of organic $\mathrm{C}$ from litter to soil in the latter case. Both influences are, in turn, associated with soil physical and biological conditions, and organic matter decomposition rates, that may locally prevail under the three shrub species studied, and that is also reported in literature (Madeira et al. 2002; Martins et al. 2007; Martins et al. 2009; Post and Kwon, 2000; Yimer et al. 2006; Zheng et al. 2008). These soil organic $C$ amounts are higher than those reported by other authors in $20 \mathrm{~cm}$ of soil depth. Perez-Quezada et al. (2011) referred 18.7 $\mathrm{Mg} \mathrm{C}^{-1}$ in a Mediterranean arid shrubland (Chile) and Bonino (2006) referred $22.9 \mathrm{Mg} \mathrm{C}^{-1}$ in shrubby grassland under a pronounced dry season (Argentina).

However, compared with other ecosystems, SOC storage is relatively lower than that found by Fernández-Núñez et al. (2010) until $25 \mathrm{~cm}$ of depth in silvopastoral systems one decade after established with $P$. radiata (130.7 $\mathrm{Mg} \mathrm{C} \mathrm{ha}^{-1}$ ) and Betula alba (143.4 Mg C ha-1) in NW Spain, where vegetation strata complexity and biomass production are also much higher than that found in the PNM shrubs studied, due to either vegetation type or to climatic conditions that favor biomass vegetation growth. Nunes et al. (2010) reported for first $30 \mathrm{~cm}$ of soils developed under $P$. pinaster in NW Portugal values that ranged from 90.2 to $123.9 \mathrm{Mg} \mathrm{C} \mathrm{ha}^{-1}$. As found in other studies (Grigal and Berguson 1998; Martins et al. 2007; Percival et al. 2000; Post and Kwon 2000; Zheng et al. 2008), a large number of soil organic compounds are intimately associated with mineral soil particles, and the turnover rate of SOC compounds varies due to the quality and distribution of organic inputs and soil organo-mineral interactions, both influencing the most important variations in soil carbon stocks and soil physical properties, as it is the case of bulk density (Don et al. 2007; Gifford and Roderick 2003; Ordóñez et al. 2008).

In fact, for low SOC, bulk density is not visibly affected by $\mathrm{C}$ concentration in soil and, therefore, soil $\mathrm{C}$ storage depends mainly on $\mathrm{C}$ concentration, meaning a positive relationship between these two variables; however, for high SOC, bulk density is visibly and negatively affected by $\mathrm{C}$ concentration in soil, meaning that the increase in $\mathrm{C}$ concentration may not be enough to compensate that decrease in the solid mass per unit bulk volume occurring when SOC is very high.

Total C storage is a sum of contributions from the system compartments and so, it directly relates to vegetation cover (above and belowground biomass), litter accumulated on soil surface and soil organic carbon. However, soil is the final destination for most of the $\mathrm{C}$ fixed by photosynthesis in terrestrial ecosystems, thus being an important sink of atmospheric $\mathrm{CO}_{2}$ (Lal 2004). Results show that, among those systems, shrub communities may have a relevant role to play on this issue, as part of agroforestry landscapes of the Mediterranean mountain areas.

\section{Conclusions}

The average $\mathrm{C}$ concentration of aboveground (56\%) and belowground biomass $(54 \%)$ is significantly higher than the value of $50 \%$ frequently used for $\mathrm{C}$ estimates, and therefore it seems necessary to limit the generalized application of that value. The $\mathrm{C}$ concentration in litter produced under E. australis is lower (38\%) than other species (50 and $47 \%$ for $C$. ladanifer and $C$. multiflorus, respectively), meaning that the decomposition rate is higher under the former species, with positive effects on SOC. Soil carbon storage in the topsoil $(0-20 \mathrm{~cm})$ is similar in all species, but tends to be higher in soil under E. australis. 
Total C storage in the whole system is significantly higher for E. australis $\left(12.8 \mathrm{~kg} \mathrm{C} \mathrm{m}^{-2}\right)$ followed by C. ladanifer $\left(10.7 \mathrm{~kg} \mathrm{C} \mathrm{m}^{-2}\right)$ and C. multiflorus $\left(10.5 \mathrm{~kg} \mathrm{C} \mathrm{m}^{-2}\right)$. More than $80 \%$ of $\mathrm{C}$ is stored in the soil, the biomass contribution being quite variable with species, and litter representing less than $3 \%$, in all species. Based on these results it is concluded that shrub communities are important terrestrial carbon pools. More attention should then be paid to these systems due to their relevant role as terrestrial carbon stocks.

Acknowledgments The authors wish to thank Escola Superior Agrária de Bragança for the material and financial support provided, that contributed to make this study possible. The contributions of Arsénio Araújo, for his assistance in the field work, and of Rita Diz and Ana Pinto, for performing the carbon analyses, are both much acknowledged.

\section{References}

Agroconsultores and Coba (1991) Carta dos Solos do Nordeste de Portugal. UTAD, Vila Real

Aguiar C, Carvalho A, Lourenço J (1992) Contribuição para o Plano de Ordenamento do Parque Natural de Montesinho: Flora e Vegetação. Escola Superior Agrária de Bragança, Bragança

Aguiar C, Rodrigues O, Azevedo J, Domingos T (2009) Montanha. In: Pereira HM et al (eds) Ecossistemas e bem-estar humano: avaliação para Portugal do Millennium Ecosystem Assessment. Escolar Editora, Lisboa, pp 295-339

Alegre J, Alonso-Blázquez N, Andrés EF, Tenorio JL, Ayerbe L (2004) Revegetation and reclamation of soils using wild leguminous shrub in cold semiarid Mediterranean conditions: litterfall and carbon and nitrogen returns under two aridity regimes. Plant Soil 263:203-212

Arevalo CBM, Bhatti JS, Chang SX, Sidders D (2009) Ecosystem carbon stocks and distribution under different landuses in north central Alberta, Canada. For Ecol Manage 257:1776-1785

Bing K, Shirong L, Guangjun Z, Jianguo C, Yuanguang W, Jiangming M, Wenfeng H (2006) Carbon accumulation and distribution in Pinus massoniana and Cunninghamia lanceolata mixed forest ecosystem in Daqingshan, Guangxi, China. Acta Ecologica Sinica 26:1320-1329

Bompastor A, Figueiredo T de, Fonseca F (2009) Matos do Parque Natural de Montesinho, NE de Portugal - Produção de serviços ecossistémicos. In: Actas do $3^{\circ}$ Congresso de Gestão e Conservação da Natureza, APDR, Cidade da Praia, Cabo Verde, pp 338-364

Bonino EE (2006) Changes in carbon pools associated with a land-use gradient in the Dry Chaco, Argentina. For Ecol Manage 223:183-189

Castro J (2010) Land use, landscape and sustainability: examples from Montesinho. In: Evelpidou N, Figueiredo T, Mauro F, Tecim V, Vassilopoulos A (eds) Natural heritage from East to West: case studies from $6 \mathrm{EU}$ countries. Springer, Berlin, pp 151-154
Castro J, de Figueiredo T, Fonseca F, Castro JP, Nobre S, Pires LC (2010) Montesinho Natural Park: general description and natural values. In: Evelpidou N, Figueiredo T, Mauro F, Tecim V, Vassilopoulos A (eds) Natural heritage from East to West: case studies from 6 EU countries. Springer, Berlin, pp 119-132

Cerqueira Y, Araújo C, Vicente J, Pereira HM, Honrado J (2010) Ecological and cultural consequences of agricultural abandonment in the Peneda-Gerês National Park (Portugal). In: Evelpidou N, Figueiredo T, Mauro F, Tecim V, Vassilopoulos A (eds) Natural heritage from East to West: case studies from 6 EU countries. Springer, Berlin, pp 175-183

Cerrilo RMN, Oyonarte PB (2006) Estimation of above-ground biomass in shrubland ecosystems of southern Spain. Investigación Agraria: Sistemas y Recursos Forestales 15(2): 197-207

Chojnacky DC, Milton M (2008) Measuring carbon in shrubs. In: Hoover CM (ed) Field measurements for forest carbon monitoring: a landscape-scale approach. Springer, New York, pp 45-72

Coomes DA, Allena RB, Scottb NA, Goulding C, Beet P (2002) Designing systems to monitor carbon stocks in forests and shrublands. For Ecol Manage 164:89-108

Curt T, Lucot E, Bouchaud M (2001) Douglas-fir root biomass and rooting profile in relation to soils in a mid-elevation area (Beaujolaia Mounts, France). Plant Soil 233:109-125

de Figueiredo T (2010) Montesinho and the mountains of Northern Portugal: introduction. In: Evelpidou N, Figueiredo T, Mauro F, Tecim V, Vassilopoulos A (eds) Natural heritage from East to West: case studies from $6 \mathrm{EU}$ countries. Springer, Berlin, pp 111-118

Dixon RK, Brown S, Houghton RA, Solomon AM, Trexler MC, Wisniewski J (1994) Carbon pools and flux of global forest ecosystems. Science 263:185-190

Don A, Schumacher J, Scherer-Lorenzen M, Scholten T, Schulze ED (2007) Spatial and vertical variation of soil carbon at two grassland site: implications for measuring soil carbon stocks. Geoderma 141:272-282

Fan JW, Zhong HP, Harris W, Yu GR, Wang SQ, Hu ZM, Yue YZ (2008) Carbon storage in the grasslands of China based on field measurements of above- and below-ground biomass. Climatic Change 86:375-396

FAO (2007) The state of food and agriculture. FAO Agriculture series, p 38

Fernández-Núñez E, Rigueiro-Rodríguez A, Mosquera-Losada MR (2010) Carbon allocation dynamics one decade after afforestation with Pinus radiata D. Don and Betula alba $\mathrm{L}$. under two stand densities in NW Spain. Ecol Eng 36: 876-890

Figueiredo T (1990) Aplicação da equação universal de perda de solo na estimativa da erosão potencial: o caso do Parque Natural de Montesinho. Bragança

Gedroc JJ, McConnaughay KDM, Coleman JS (1996) Plasticity in root/shoot partitioning: optimal, ontogenetic, or both? Funct Ecol 10:44-50

Gifford RM, Roderick ML (2003) Soil carbon stocks and bulk density: spatial or cumulative mass coordinates as a basis of expression? Glob Change Biol 9:1507-1514

Goetz SJ, Prince S (1998) Variability in carbon exchange and light utilisation among boreal forest stands: implications 
for remote sensing of net primary production. Can J For Res 28:375-389

Gower ST, Vogel JG, Norman JM, Kucharik CJ, Steele SJ, Stow TK (1997) Carbon distribution and above-ground net primary production in aspen, jack pine and black spruce stands in Saskatchewan and Manitoba, Canada. J Geophys Res 102:29029-29041

Grigal DF, Berguson WE (1998) Soil carbon changes associated with short-rotation systems. Biomass Bioenergy 14(4): 371-377

Guilherme CA, Linda SC, Haridasan M, Eiten G (1998) Above and belowground organic matter and root:shoot ratio in a Cerrado in Central Brazil. Braz J Ecol 2(1):11-23

Hilbert DW, Canadell J (1995) Biomass partitioning and resource allocation of plants from Mediterranean-type ecosystems: possible responses to elevated atmospheric $\mathrm{CO}_{2}$. In: Oechel WC, Moreno J (eds) Anticipated effects of a changing global environment on Mediterranean-type ecosystems. Springer, Berlin, pp 76-101

Houghton RA, Skole DL, Nobre CA (2000) Annual fluxes of carbon from deforestation and regrowth in the Brazilian Amazon. Nature 403:301-304

IPB/ICN (2006) Plano de Ordenamento do Parque Natural de Montesinho: I - Relatório de caracterização. Instituto Politécnico de Bragança, Portugal

IPCC (2001) Climate Change. The synthesis report. Cambridge University Press, UK

ISO (1994) Organic and total carbon after dry combustion. In: Environment soil quality. ISO/DIS 10694

José S (2009) Agroforestry for ecosystems services and environmental benefits: an overview. Agrofor Syst 76:1-10

Jurado E, Westoby M (1992) Seedling growth in relation to seed size among species of arid Australia. J Ecol 80:407-416

Keeley JE (1998) Coupling, demography, physiology and evolution in chaparral shrubs. Ecol Stud 136:257-264

Klein D, Fuentes JP, Schmidt A, Schmidt H, Schulte A (2008) Soil organic $\mathrm{C}$ as affect by silvicultural and exploitative interventions in Nothofagus pumilio forests of the Chilean Patagonia. For Ecol Manage 255:3549-3555

Kuemmerle T, Hostert P, Radeloff VC, van der Linden S, Perzanowski K, Kruhlov I (2008) Cross-border comparison of post-socialist farmland abandonment in the Carpathians. Ecosystems 11:614-628

Kummerow J, Kraus D, Jow W (1977) Root systems of chaparral shrubs. Oecologia 29:163-177

Lal R (2004) Soil carbon sequestration impacts on global climate change and food security. Science 304:1623-1627

Lázaro A, Montiel C (2010) Overview of prescribed burning policies and practices in Europe and other countries. In: Silva JS, Rego F, Fernandes P, Rigolot E (eds) Towards integrated fire management: outcomes of the European project fire paradox. European Forest Institute, Torikatu, pp 137-150

Lloret F, Casanovas C, Peñuelas J (1999) Seedling survival of Mediterranean shrubland species in relation to root:shoot ratio, seed size and water and nitrogen use. Funct Ecol 13:210-216

Lufafa A, Diédhiou I, Samba SAN, Séné M, Khouma M, Kizito F, Dick RP, Dossa E, Noller JS (2008) Carbon stocks and patterns in native shrub communities of Senegal's Peanut Basin. Geoderma 146:75-82
MacClaran MP, Moore-Kucera J, Martens DA, van Haren J, Marsh SE (2008) Soil carbon and nitrogen in relation to shrub size and death in a semi-arid grassland. Geoderma 145:60-68

Madeira MV, Fabião A, Pereira JS, Araújo MC, Ribeiro C (2002) Changes in carbon stocks in Euvalyptus globulus Labill. plantations induced by different water and nutrient availability. For Ecol Manage 71:75-85

Martins A, Coutinho J, Costa S, Fonseca F, Madeira M (2007) A folhada de quatro povoamentos florestais no Norte de Portugal: Produção e concentração e quantidade de nutrientes devolvidos ao solo. Revista de Ciências Agrárias 30:199-214

Martins A, Azevedo S, Raimundo F, Madeira M (2009) Decomposição de folhada de quatro espécies florestais no Norte de Portugal: Taxa de decomposição e evolução da composição estrutural e do teor em nutrientes. Revista de Ciências Agrárias 32(1):223-237

Montiel C, Herrero G (2010) An overview of policies and practices related to fire ignitions at the European Union level. In: Silva JS, Rego F, Fernandes P, Rigolot E (eds) Towards integrated fire management: outcomes of the European project fire paradox. European Forest Institute, Torikatu, pp 35-46

Mooney HA, Dunn EL (1970) Convergent evolution of Mediterranean-climate evergreen sclerophyll shrubs. Evolution 24(2):292-303

Mosquera-Losada MR, McAdam JH, Romero-Franco R, Santiago-Freijanes JJ, Rigueiro-Rodríguez A (2009) Definitions and concepts of agroforestry practices in Europe. In: Rigueiro-Rodríguez A, McAdam J, Mosquera-Losada MR (eds) Agroforestry in Europe. Springer, Berlin, pp 3-19

Nair PKR (2011) Carbon sequestration studies in agroforestry systems: a reality-check. Agrofor Syst. doi:10.1007/s10457011-9434-Z

Nicolini F, Topp W (2005) Soil properties in plantations of sessile oak (Quercus petraea) and red oak (Quercus rubra) in reclaimed lignite open-cast mines of the Rhineland. Geoderma 129:65-72

Noy-Meir I (1973) Desert ecosystems: environment and producers. Annu Rev Ecol Syst 4:25-49

Nuberg I, Reid R, George B (2009) Agroforestry as integrated natural resource management. In: Nuberg I, George B, Reid R (eds) Agroforestry for natural resource management. CSIRO Publishing, Collingwood, pp 1-20

Nunes A (2008) Abandono do espaço agrícola na Beira Transmontana. Iberografias, 13 ed. Campo das Letras SA

Nunes L, Patricio M, Tomé J, Tomé M (2010) Carbon and nutrients stocks in even-aged maritime pine stands from Portugal. Forest Systems 19:434-448

Ordóñez JAB, de Jong BHJ, García-Oliva F, Aviña FL, Pérez JV, Guerrero G, Martínez R, Masera O (2008) Carbon content in vegetation, litter and soil under 10 different land-use and land-cover classes in the Central Highlands of Michoacan, Mexico. For Ecol Manage 255:2074-2084

Percival HJ, Parfitt RL, Scott NA (2000) Factors controlling soil carbon levels in New Zealand grasslands: is clay content important? Soil Sci Soc Am J 64:1623-1630

Perez-Quezada JF, Delpiano CA, Snyder KA, Johnson DA, Franck N (2011) Carbon pools in an arid shrubland in Chile 
under natural and afforested conditions. J Arid Environ 75:29-37

Pinno BD, Bélanger N (2008) Ecosystem carbon gains from afforestation in the boreal transition ecozone of Saskatchewan (Canada) are coupled with the devolution of black chernozems. Agric Ecosyst Environ 123:56-62

Post WM, Kwon KC (2000) Soil carbon sequestration and landuse change: processes and potential. Glob Change Biol 6:317-327

Rees RM, Bingham IJ, Baddeley JA, Watson CA (2005) The role of plants and land management in sequestering soil carbon in temperate arable and grassland ecosystems. Geoderma 128:130-154

Sharma P, Rai SC (2007) Carbon sequestration with land-use cover change in a Himalayan watershed. Geoderma 139:371-378

Sierra CA, del Valle JI, Orrego SA, Moreno FH, Harmon ME, Zapata M, Colorado GJ, Herrera MA, Lara W, Restrepo DE, Berrouet LM, Loaiza LM, Benjumea JF (2007) Total carbon stocks in a tropical forest landscape of the Porce region, Colombia. For Ecol Manage 243:299-309

Silva JS, Rego FC, Martins-Loução MA (2003) Root distribution of Mediterranean woody plants. Introducing a new empirical model. Plant Biosystems 137(1):63-72

Steel RGD, Torrie JH (1980) Principles and procedures of statistics: a biometrical approach. Mc-Graw Hill, New York
Tang H, Qiu J, Van Ranst E, Li C (2006) Estimations of soil organic carbon storage in cropland of China based on DNDC model. Geoderma 134:200-206

Tate KR, Giltrap DJ, Claydon JJ, Newsome PJ, Atkinson IAE, Tayler MD, Lee R (1997) Organica carbon stocks in New Zealands terrestrial ecosystems. J Roy Soc New Zeal 27:315-335

Vargas DN, Bertiller MB, Ares JO, Carrera AL, Sain CL (2006) Soil $\mathrm{C}$ and $\mathrm{N}$ dynamics induced by leaf-litter decomposition of shrubs and perennial grasses of the Patagonian Monte. Soil Biol Biochem 38:2401-2410

Yimer F, Ledin S, Abdelkadir A (2006) Soil organic carbon and total nitrogen stocks as affected by topographic aspect and vegetation in the Bale Mountains, Ethiopia. Geoderma 135:335-344

Zhang J, Ge Y, Chang J, Jiang B, Jiang H, Peng C, Zhu J, Yuan W, Qi L, Yu S (2007) Carbon storage by ecological service forests in Zhejiang Province, subtropical China. For Ecol Manage 245:64-75

Zhang Y, Zhao YC, Shi XZ, Lu XX, Yu DS, Wang HJ, Sun WX, Darilek JL (2008) Variation of soil organic carbon estimates in mountain regions: a case study from Southwest China. Geoderma 146:449-456

Zheng H, Ouyang Z, Xu W, Wang X, Miao H, Li X, Tian Y (2008) Variation of carbon storage by different reforestation types in the hilly red soil region of southern China. For Ecol Manage 255:1113-1121 